ARTICLE

\title{
Highly selective inhibition of histone demethylases by de novo macrocyclic peptides
}

Akane Kawamura ${ }^{1,2}$, Martin Münzel ${ }^{1, \star, \dagger}$, Tatsuya Kojima ${ }^{3, \star}$, Clarence Yapp $^{4,5}$, Bhaskar Bhushan ${ }^{1,2}$, Yuki Goto $^{3}$, Anthony Tumber ${ }^{4,5}$, Takayuki Katoh ${ }^{3}$, Oliver N.F. King ${ }^{1}$, Toby Passioura ${ }^{3}$, Louise J. Walport ${ }^{1}$, Stephanie B. Hatch ${ }^{4,5}$, Sarah Madden ${ }^{1}$, Susanne Müller ${ }^{4,5, \dagger}$, Paul E. Brennan ${ }^{4,5}$, Rasheduzzaman Chowdhury ${ }^{1}$, Richard J. Hopkinson ${ }^{1}$, Hiroaki Suga ${ }^{3,6} \&$ Christopher J. Schofield ${ }^{1}$

The JmjC histone demethylases (KDMs) are linked to tumour cell proliferation and are current cancer targets; however, very few highly selective inhibitors for these are available. Here we report cyclic peptide inhibitors of the KDM4A-C with selectivity over other KDMs/ $20 \mathrm{G}$ oxygenases, including closely related KDM4D/E isoforms. Crystal structures and biochemical analyses of one of the inhibitors (CP2) with KDM4A reveals that CP2 binds differently to, but competes with, histone substrates in the active site. Substitution of the active site binding arginine of CP2 to $N$ - $\varepsilon$-trimethyl-lysine or methylated arginine results in cyclic peptide substrates, indicating that KDM4s may act on non-histone substrates. Targeted modifications to CP2 based on crystallographic and mass spectrometry analyses results in variants with greater proteolytic robustness. Peptide dosing in cells manifests KDM4A target stabilization. Although further development is required to optimize cellular activity, the results reveal the feasibility of highly selective non-metal chelating, substrate-competitive inhibitors of the JmjC KDMs.

\footnotetext{
${ }^{1}$ Chemistry Research Laboratory, Department of Chemistry, University of Oxford, 12 Mansfield Road, Oxford OX1 3TA, UK. ${ }^{2}$ Division of Cardiovascular Medicine, Radcliffe Department of Medicine, Wellcome Trust Centre for Human Genetics, Roosevelt Drive, Oxford OX3 7BN, UK. ${ }^{3}$ Department of Chemistry, Graduate School of Science, The University of Tokyo, 7-3-1 Hongo, Bunkyo-Ku, Tokyo 113-0033, Japan. ${ }^{4}$ Structural Genomics Consortium, University of Oxford, Old Road Campus Roosevelt Drive, Headington OX3 7DQ, UK. ${ }^{5}$ Nuffield Department of Medicine, Target Discovery Institute, University of Oxford, Roosevelt Drive, Oxford OX3 7FZ, UK. ${ }^{6}$ JST, CREST, 7-3-1 Hongo, Bunkyo-Ku, Tokyo, 113-0033, Japan. * These authors have contributed equally to the work. $\dagger$ Present addresses: Novo Nordisk A/S, Novo Nordisk Park, 2760 Måløv, Denmark (M.M.); Structural Genomics Consortium, Goethe Universität Frankfurt, Buchmann Institute for Molecular Life Sciences, Riedberg Campus, Max-von-Laue-Str. 15, 60438 Frankfurt am Main, Germany (S.M.). Correspondence and requests for materials should be addressed to A.K. (email: akane.kawamura@chem.ox.ac.uk) or to H.S. (email: hsuga@chem.s.u-tokyo.ac.jp) or to C.J.S. (email: christopher.schofield@chem.ox.ac.uk).
} 
E ukaryotic gene expression is substantially regulated by a complex set of covalent modifications to DNA and histones ${ }^{1,2}$. Aberrant histone modifications are associated with diseases, including cancer, inflammatory disorders, neurological and cardiovascular diseases ${ }^{3,4}$. The multi-domain proteins that read and write posttranslational histone modifications are often mutated/dysregulated in such diseases. Structural similarities between individual domains of these 'epigenetic' proteins make the identification of potent and selective inhibitors of these proteins challenging.

Histone lysine methylation is dynamically regulated by methyltransferases and demethylases (KDMs). Two families of human KDMs catalyse the removal of methyl groups from methylated lysines on histone tails in a sequence- and methylationstate-dependent manner ${ }^{5}$; the flavin-dependent lysine-specific demethylases (KDM1/LSD) ${ }^{6}$ and the JmjC-domain containing KDMs (JmjC-KDMs), which are Fe(II) and 2-oxoglutarate (2OG)dependent oxygenases (KDM2-7) 7,8 . Only a few JmjC-KDM inhibitors are reported, the majority of which operate via active-site metal chelation ${ }^{9}$. Achieving both selectivity and potency for specific JmjC-KDMs remains a major challenge?

Natural product screening is an attractive method for identifying inhibitor hits and leads. However, natural productbased structure activity studies are often limited by difficulties in synthesis and/or systematically manipulating the output of biosynthesis. An alternative approach, Random nonstandard Peptides Integrated Discovery (RaPID) system has been developed, which involves efficient selection using ribosomally expressed 'natural product'-inspired macrocycles ${ }^{10,11}$. De novo macrocycles that tightly bind to target proteins can be efficiently selected from the $>10^{12}$ members of the library; derivatives of the initial hits are then chemically synthesized for structural optimizaion $^{11-13}$.

We describe the use of the RaPID methodology for discovery of highly selective and potent cyclic peptide inhibitors of KDMs, which, after structure- and activity-guided modifications, show evidence of on-target engagement in cells. We targeted the KDM4 subfamily, which represent biomedically attractive but challenging targets. Although the catalytic domains (JmjC-domain) and active sites are highly conserved, all KDM4s remove the repressive H3K9me3 mark, but only KDM4A-C are additionally capable of demethylating the activating $\mathrm{H} 3 \mathrm{~K} 36 \mathrm{me} 3 \mathrm{mark}^{14,15}$. Intra-subfamily selective inhibitors will be useful tools to dissect the roles of the opposing histone modifications and of the KDM4 isoforms in disease.

\section{Results}

Identification of potent KDM4A-C-selective cyclic peptides. A messenger RNA template library was designed with the general form AUG-(NNK) $4-12$-UGC, where the AUG start codon was reassigned from Met to either $N$-chloroacetyl-L-Tyr or $N$-chloroacetyl-D-Tyr, which induce cyclization of the translated peptides through reaction with an appropriately positioned cysteine (UGC) downstream of the random sequence to yield lantibiotic-like thioether rings ${ }^{16,17}$. The selection used two thioether-macrocycle libraries ( ${ }^{\mathrm{T}} \mathrm{Tyr}$ and ${ }^{\mathrm{D}} \mathrm{Tyr}$ libraries) ${ }^{12}$ with screening against the catalytic domain of His-tagged KDM4A (residues 1-359) (Fig. 1 and Supplementary Fig. 1a). Enriched complementary DNA pools from both libraries were cloned and analysed. Out of 21 (D $\mathrm{T}$ yr-library) and 23 ( ${ }^{\mathrm{L}} \mathrm{Tyr}-$ library) clones sequenced (Supplementary Fig. 1b,c), five cyclic sequences (CP1-5, 11-14 residues in length) were selected for further analysis based on hit frequency and similarity; these were synthesized by solid-phase peptide synthesis. Catalytic inhibition of KDM4A/C by the selected peptides was tested using a luminescence-based AlphaScreen activity assay ${ }^{18}$. From the KDM4A screen, two cyclic peptides (CP2 and CP4) demonstrated potencies of half-maximal inhibitory concentration $\left(\mathrm{IC}_{50}\right)<50 \mathrm{nM}$ against KDM4A (Table 1); CP5 was less potent $\left(\mathrm{IC}_{50}<500 \mathrm{nM}\right)$. The other two hits $(\mathrm{CP} 1$ and $\mathrm{CP} 3)$ were much less effective $\left(\mathrm{IC}_{50}>100 \mu \mathrm{M}\right)$.

Clear selectivity (that is, $>160$-fold by $\mathrm{IC}_{50}$ ) of all inhibitory CPs (CP2, CP4 and CP5) was observed for KDM4 over representatives from four other human JmjC-demethylase families and two related 2OG oxygenases, prolyl hydroxylase domain 2 and factor inhibiting HIF, as well as a flavin-dependent $\mathrm{KDM}$ (KDM1A), indicating that these CPs are exceptionally selective (Table 1). Intra-subfamily selectivity was then investigated by determining $\mathrm{IC}_{50}$ values across all KDM4 subfamily members. CP2 and CP4 displayed high potency $\left(\mathrm{IC}_{50}<50 \mathrm{nM}\right)$ against KDM4A-C; importantly, they were much less active against KDM4D-E, revealing intra-subfamily selectivity of $>100$-fold and that the CPs are therefore even capable of distinguishing the subtle differences between $\mathrm{KDM} 4 \mathrm{~A}-\mathrm{C}$ and $\mathrm{KDM} 4 \mathrm{D} / \mathrm{E}$. Binding studies demonstrated that CP2, CP4 and CP5 are tight binders of KDM4A with slow on and off rates; in contrast, the histone $\mathrm{H} 3 \mathrm{~K} 9$ peptide (KDM4A substrate) exhibits substantially faster on/off rates and weaker binding affinity $\left(K_{\mathrm{d}}>1,000\right.$-fold; Table 1 and Supplementary Fig. 2a,b). Kinetic analyses with CP2 revealed it is a competitive inhibitor with respect to $\mathrm{H} 3 \mathrm{~K} 9 \mathrm{me} 3$ (Supplementary Fig. 2c). CP2 also inhibits the demethylation activity of full-length KDM4A (residues 1-1,064) purified from HEK293T cells (Supplementary Fig. 3), indicating $\mathrm{CP} 2$ can inhibit KDM4A when other domains (for example, PHD/tudor domains) are present.

CP2 uniquely binds in the KDM4A substrate-binding pocket. To investigate the structural basis of the unprecedented selectivity of the cyclic peptides, we crystallized CP2 with KDM4A (2.7 A resolution, Fig. 2a). Interestingly, the structure reveals that $\mathrm{CP} 2$ occupies the histone-binding groove of KDM4A, but not the 2OG-binding pocket, the latter of which has been exploited for most reported $2 \mathrm{OG}$ oxygenase, including JmjC KDM, inhibitors. Moreover, CP2 exhibits a binding mode, which partially overlaps, but which is clearly distinct from those observed for $\mathrm{H} 3 \mathrm{~K} 9 \mathrm{me}(n)$ and $\mathrm{H} 3 \mathrm{~K} 36 \mathrm{me}(n)$ histone substrates (Fig. 2b). Analysis of the inhibitor conformation revealed that $\mathrm{CP} 2$ adopts a distorted $\beta$-sheet fold with two turns; a type $1 \beta$-turn (Thr5-Gly8) is closest of the two $\beta$-turns to the active site metal (Fig. 2c). CP2 engages in multiple hydrogen bonds with KDM4A, many of which are not observed in the reported structures of KDM4A-H3K9me3 (PDB 2OQ6) and KDM4A-H3K36me3 enzyme substrate complexes $(\mathrm{PDB} 2 \mathrm{P} 5 \mathrm{~B})^{19}$. Strikingly, the structure reveals Arg6-CP2 bound in the sub-pocket usually occupied by the extended trimethyllysine side chain of the $\mathrm{H} 3 \mathrm{~K} 9$ and $\mathrm{K} 36$ substrate residues. In addition to mimicking the positive charge of the lysine, the guanidino group of Arg6-CP2 is positioned to make hydrogen bonds with KDM4A residues (Tyr177, Ser288 and Asn290; Supplementary Fig. 4a,b). Two KDM4A residues in the CP2complexed structure (Tyr175 and Arg309) move, relative to uncomplexed KDM4A, to open pockets that accommodate CP2, suggesting flexibility in these regions. The Arg309 side chain rotates by approximately $90^{\circ}$ relative to the $\mathrm{H} 3 \mathrm{~K} 9 \mathrm{me} 3 /$ H3K36me3 bound KDM4A structures to accommodate Trp9CP2 (Fig. 2d,e). Tyr175 also shifts by approximately $90^{\circ}$ to accommodate Arg6-CP2 (Fig. 2f). This movement relocates an adjacent loop (between $\alpha 6$ and DSBH $\beta \mathrm{I}$ ( $\beta 7$ ), residues 161-173), which resembles a conformation found in $\mathrm{KDM} 4 \mathrm{C}(\mathrm{apo})$ structure (Fig. 2f). Other notable conformational changes in the KDM4A residues induced by CP2 binding include at Lys241 and Asp311 (Supplementary Fig. 5). 


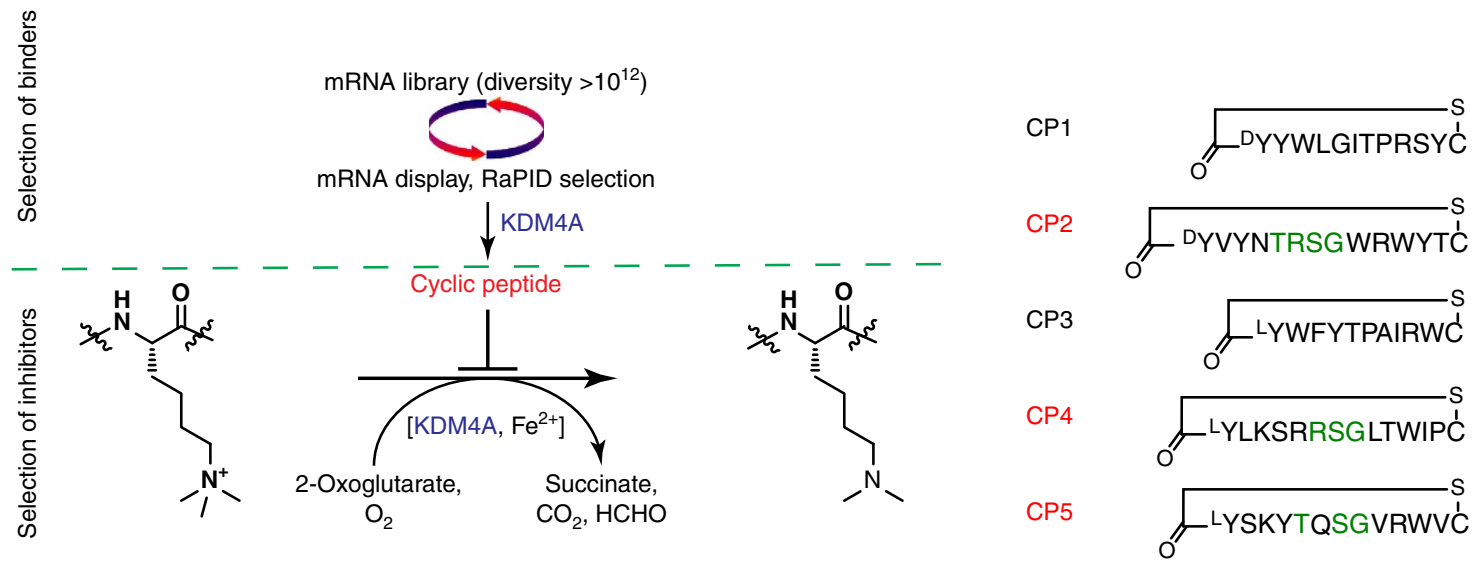

Figure 1 | Development of KDM4A cyclic peptide inhibitors. Cyclic peptide binders of KDM4A were selected using the RaPID system (Supplementary Fig. 1). The hit peptide sequences (CP1-CP5) were synthesized and further tested in enzymatic assays. Peptides were cyclized by a thioether formation.

Table 1 | Potency and selectivity of cyclic peptide hits from the RaPID system.

\begin{tabular}{|c|c|c|c|c|c|}
\hline & CP1 & CP2 & CP3 & CP4 & CP5 \\
\hline KDM4B & - & 33 & - & 6 & 472 \\
\hline KDM4C & - & 39 & $>10^{5}$ & 17 & 123 \\
\hline KDM4D & - & 6,270 & - & 6,260 & $>10^{4}$ \\
\hline KDM3A & - & $>10^{4}$ & - & 9,900 & $>10^{4}$ \\
\hline KDM5C & - & $>10^{4}$ & - & $>10^{4}$ & $>10^{4}$ \\
\hline KDM6B & - & 6,800 & - & 7,200 & $>10^{4}$ \\
\hline KDM1A & - & $>10^{4}$ & - & $>10^{4}$ & $>10^{4}$ \\
\hline PHD2 & - & $>10^{6}$ & - & $>10^{6}$ & $>10^{6}$ \\
\hline $\mathrm{FIH}$ & - & $>10^{6}$ & - & $>10^{6}$ & $>10^{6}$ \\
\hline$k_{\text {diss }}(1 / s)$ & & $4.07 \times 10^{-3}$ & & $7.84 \times 10^{-4}$ & $1.07 \times 10^{-2}$ \\
\hline \multicolumn{6}{|c|}{ 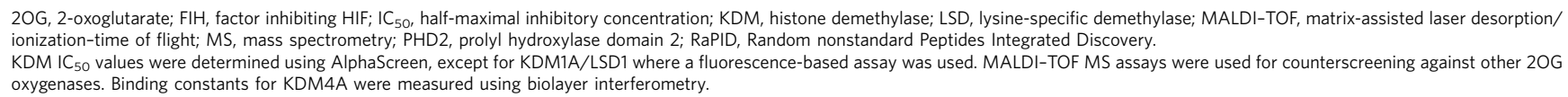 } \\
\hline
\end{tabular}

Although the linearized sequence of CP2 maintains modest activity against $\mathrm{KDM} 4 \mathrm{~A}$, its $\mathrm{IC}_{50}$ is four fold higher than that of $\mathrm{CP} 2$, probably due to the increased conformational freedom of the linear sequence (Table 2, peptide 2). However, changing the stereochemistry of the 'cyclizing' amino-terminal tyrosine (D/L-Tyr) does not affect the potency of CP2 (Table 2, peptide 3); this may reflect the lack of interactions that $\mathrm{CP} 2$ makes with KDM4A in the regions surrounding the thioether bond (Tyr1, Val2 and Tyr12-Cys14) as observed crystallographically (Fig. 2c and Supplementary Fig. 4a,b).

Analysis of the polar contacts in the KDM4A-CP2 structure provides a structural basis for the selectivity of the cyclic peptides for KDM4A-C over D/E (Supplementary Fig. 4c). Despite the sequence and structural similarity in the catalytic domains between KDM4A and KDM4D $(77 \%)^{20}, 5$ of the 14 residues directly interacting with $\mathrm{CP} 2$ in $\mathrm{KDM} 4 \mathrm{~A}-\mathrm{C}$ (Asn86, Gln88, Ser288, Arg309 and Asp311) are different in KDM4D/E. Interestingly, three of the five residues (Asn86, Gln88 and Arg309) coincide with those identified as important for the lack of activity of KDM4D/E on H3K36me3 (ref. 20).
Arg6-CP2 is a key residue for KDM4A binding. To investigate the role of Arg6 of $\mathrm{CP} 2$, which binds in a similar manner to the $\mathrm{H} 3 \mathrm{Kme}(n)$ residue, we substituted it with other residues (Table 2 and Supplementary Fig. 6); substitution with alanine (peptide 4) or with hydrophobic/uncharged side chains including $N$ - $\varepsilon$-acetyl lysine and citrulline (peptides 5, 6 and 7) leads to loss of potency $\left(\mathrm{IC}_{50}>2,400 \mathrm{nM}\right.$ for KDM4A). Inhibition of activity is regained upon substitution with positively charged residues (lysine (peptide 8) $/ N$ - $\varepsilon$-trimethyllysine (peptide 9 ),, $\mathrm{IC}_{50}=24$ and $12 \mathrm{nM}$, respectively, for KDM4A). The relevance of the crystallographically observed orientation of Arg6 in solution was explored using the trimethyl-lysine CP2 variant (peptide 9). Despite the lack of similarity between $\mathrm{CP} 2$ and the histone substrates, $N$ - $\varepsilon$-trimethyl-lysine-CP2 (R6Kme3) was efficiently demethylated by KDM4A to Kme2/Kme1/Kme0 (Fig. 3b). A co-crystal structure of $\mathrm{CP} 2(\mathrm{R} 6 \mathrm{Kme} 3)$ in complex with $\mathrm{N}$-oxalylglycine (NOG, an inactive form of 2OG) and KDM4A supports the productive binding conformation of the CP2(R6Kme3) (Fig. 3a); the acceptance of CP2(R6Kme3) as a KDM4A substrate unequivocally demonstrates that the CP2 
a

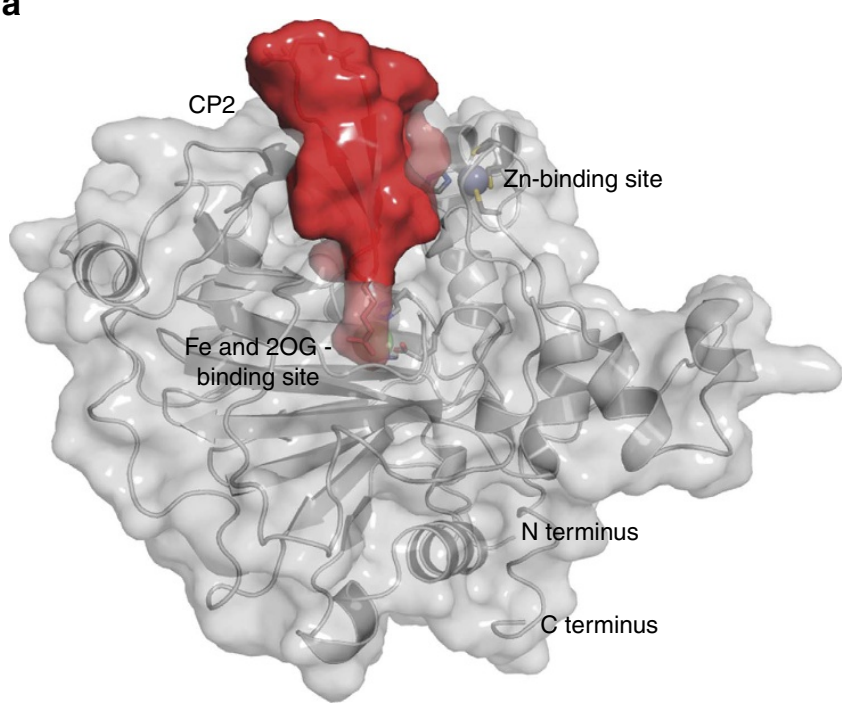

b

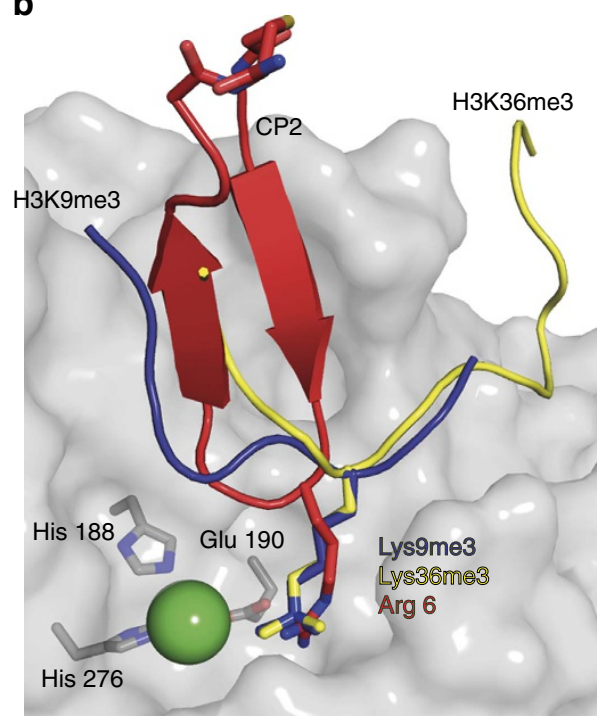

C
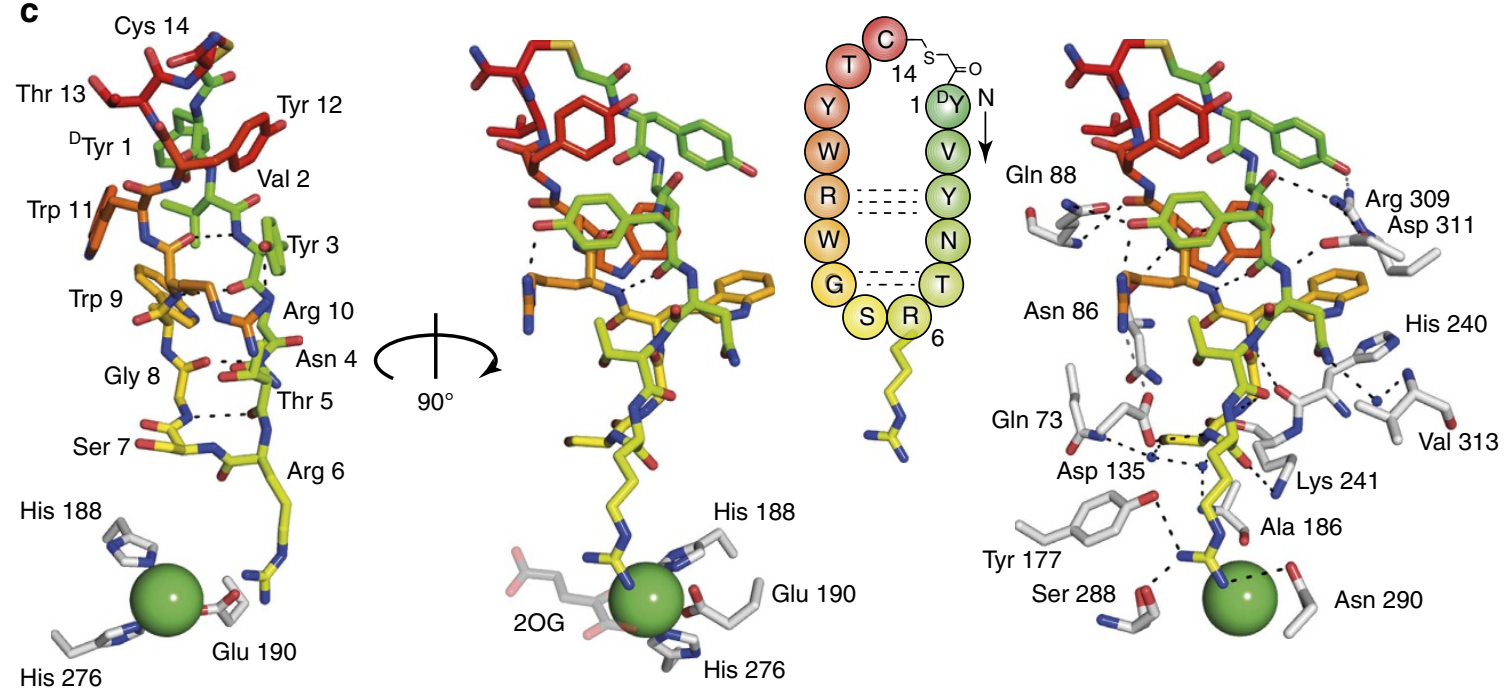

His 276

Glu 190

d

e
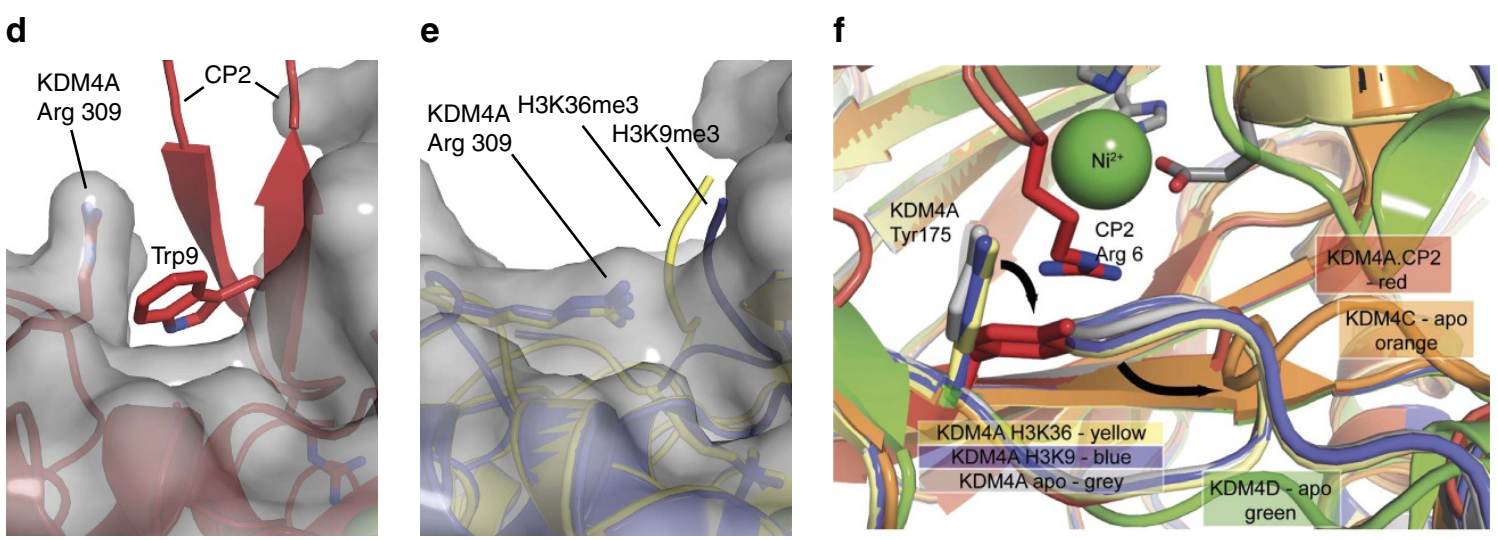

Figure 2 | Cyclic peptide (CP2) occupies the substrate binding site of KDM4A. (a) Space-filling view from a crystal structure of KDM4A complexed with CP2. (b) Overlay of CP2 with the backbones of the histone substrates (H3K9me3 (PDB 2OQ6) and H3K36me3 (PDB 2P5B)) of KDM4A. The sidechain of Arg6 projects towards the metal as observed with the Kme3 substrate sidechain. (c) CP2 adopts a twisted $\beta$-sheet fold with a type- $1 \beta$-turn at the active site and engages in an extensive hydrogen bond network (Supplementary Fig. 4) and binds in the histone substrate binding site. (d-f) CP2 binding shows distinct differences in some of the side-chain orientations of KDM4A to that induced by histone peptide binding. (d) Trp9 in CP2 induces movement of Arg309 in KDM4A, relative to the (e) histone peptide-bound KDM4A structures. (f) Movement of Tyr 175 in KDM4A is observed when bound to CP2, relative to the histone peptide bound structures of KDM4A, and induces a shift in the adjacent loop. This loop orientation is similar to that observed in the KDM4C (apo, orange (PDB 2XML)) structure. Ni(II) is substituted for Fe(II) in the KDM4A crystals. 
Table 2 | Structure activity relationships for CP2 analogues.

\begin{tabular}{|c|c|c|c|c|c|c|c|}
\hline & & \multicolumn{2}{|c|}{$I_{50}(n M)$} & & & \multicolumn{2}{|c|}{$I C_{50}(n M)$} \\
\hline & & KDM4A & KDM4C & & & KDM4A & KDM4C \\
\hline 1 & CP2 & 42 & 29 & 12 & T13Z & 110 & 60 \\
\hline 2 & Linear CP2 & 172 & 144 & 13 & C14meC & 9 & 23 \\
\hline 3 & DY1 1 Y & 66 & 78 & 14 & T13meT & 48 & 53 \\
\hline 4 & R6A & 2,700 & 3,900 & 15 & V2meV & 37 & 60 \\
\hline 5 & R6F & 5,500 & $>10^{4}$ & 16 & ${ }^{D} Y 1 m e^{D Y}$ & 264 & 192 \\
\hline 6 & R6AcK & 2,400 & 5,900 & 17 & $G 8^{D} A$ & 10 & 29 \\
\hline 7 & R6Cit & 283 & 695 & 18 & $\mathrm{G}^{\mathrm{D}} \mathrm{A} / \mathrm{Y} 12^{4 \mathrm{~F}_{\mathrm{F}}}$ & 10 & 9 \\
\hline 8 & R6K & 24 & 112 & 19 & CP2.1 & 27 & 15 \\
\hline 9 & R6Kme3 & 12 & - & 20 & CP2.2 & 100 & 274 \\
\hline \multirow[t]{2}{*}{11} & CP2(polyR) & 1.8 & 0.8 & 21 & CP2.3 & 110 & 69 \\
\hline & & & & 22 & CP2.3(R6A) & - & $>10^{4}$ \\
\hline
\end{tabular}

a

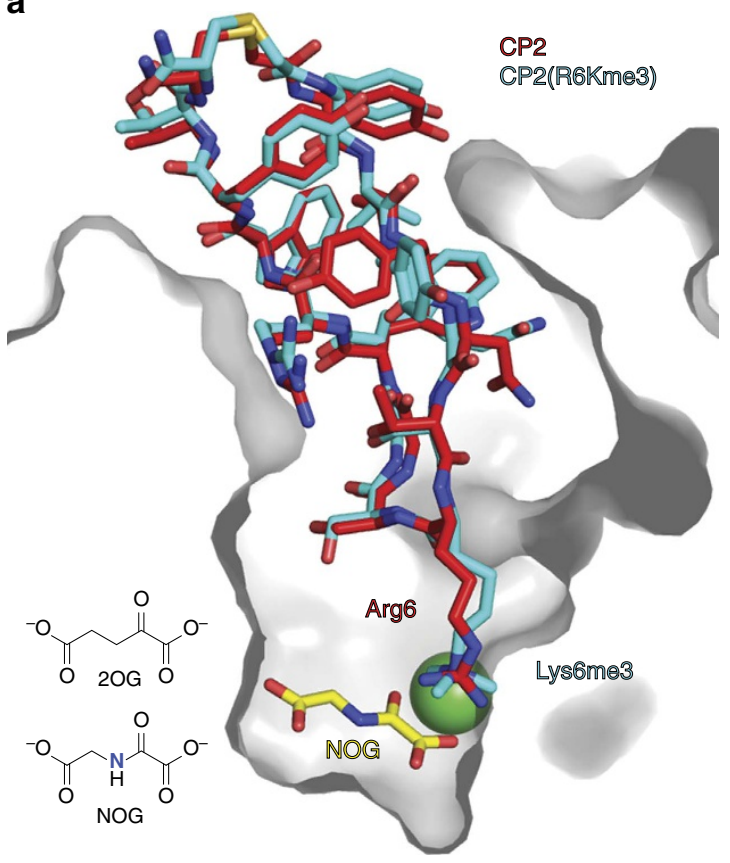

b

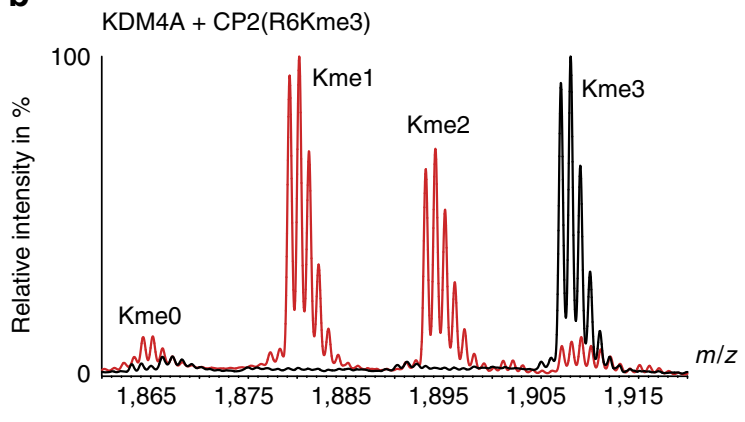

C

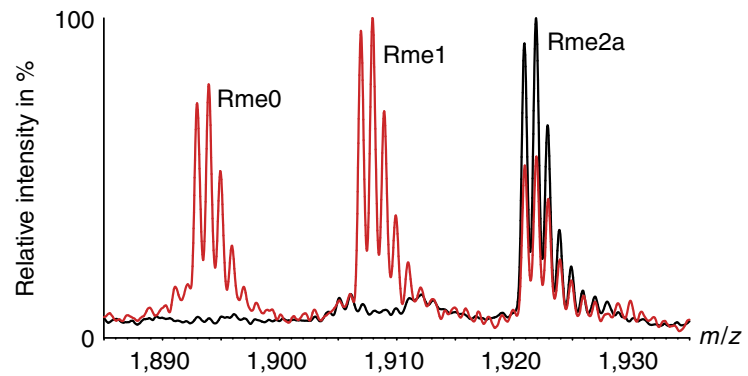

Figure 3 | KDM4A can demethylate methylated lysine and arginine containing non-histone sequences. (a) Overlay of views from crystal structures of KDM4A with CP2 (red) and CP2(R6Kme3).NOG (cyan). It is noteworthy that the binding site of NOG, an inactive 2OG analogue, is distinct from the binding site of CPs. (b) CP2(R6Kme3) (peptide 9) and (c) CP2(R6me2a) (peptide 10) are substrates of KDM4A. KDM4A $1-359$ (2 $\mu$ M) was incubated with $\mathrm{CP} 2$ variant $(10 \mu \mathrm{M})$ in the presence of $2 \mathrm{OG}(100 \mu \mathrm{M}), \mathrm{Fe}(\mathrm{II})(10 \mu \mathrm{M})$ and ascorbate $(100 \mu \mathrm{M})$ for $2 \mathrm{~h}$ at $37^{\circ} \mathrm{C}$. The reaction product was analysed using matrix-assisted laser desorption/ionization-time of flight MS. Reactions containing enzymes are in red, no enzyme peptide controls are in black.

series does not compete with 2OG. Notably, KDM4A was also able to demethylate methylated Arg6 (CP2(R6me2a), peptide 10) to the non-methylated, inhibitory CP2 sequence (Fig. 3c). The different sequences and binding modes between the well-established histone substrates (H3K9me3/K36me3) and CP2 suggests that KDM4s might be more promiscuous in their substrate selectivity and binding mode than presently perceived.

Structure-guided modifications improve stability in cells. We then investigated the utility of CP2 as a cellular probe. Strainpromoted azide-alkyne cycloaddition was used to generate CP2 derivatives with a fluorescein dye $(\mathrm{CP} 2(\mathrm{Fl}))$ (Supplementary Fig. 6a $)^{21,22}$. Time-dependent increases in intracellular fluorescence were observed in HeLa cells dosed with CP2(Fl), indicating cellular uptake (Supplementary Fig. 7). The fluorescence signal was observed to accumulate outside the nucleus $(>10 \mathrm{~h})$, possibly indicating peptide degradation. Cellular thermal shift assays (CETSA) ${ }^{23}$ were then used to investigate intracellular target engagement of CP2 in cells. U2OS cells ectopically expressing FLAG-tagged $\mathrm{KDM}_{4} \mathrm{~A}_{1-1,064}$ were dosed with CPs for $20 \mathrm{~h}$, harvested, washed and the intact cells were subjected to a temperature gradient. CETSA melt curves were determined for KDM4A and actin by western blot analysis. 

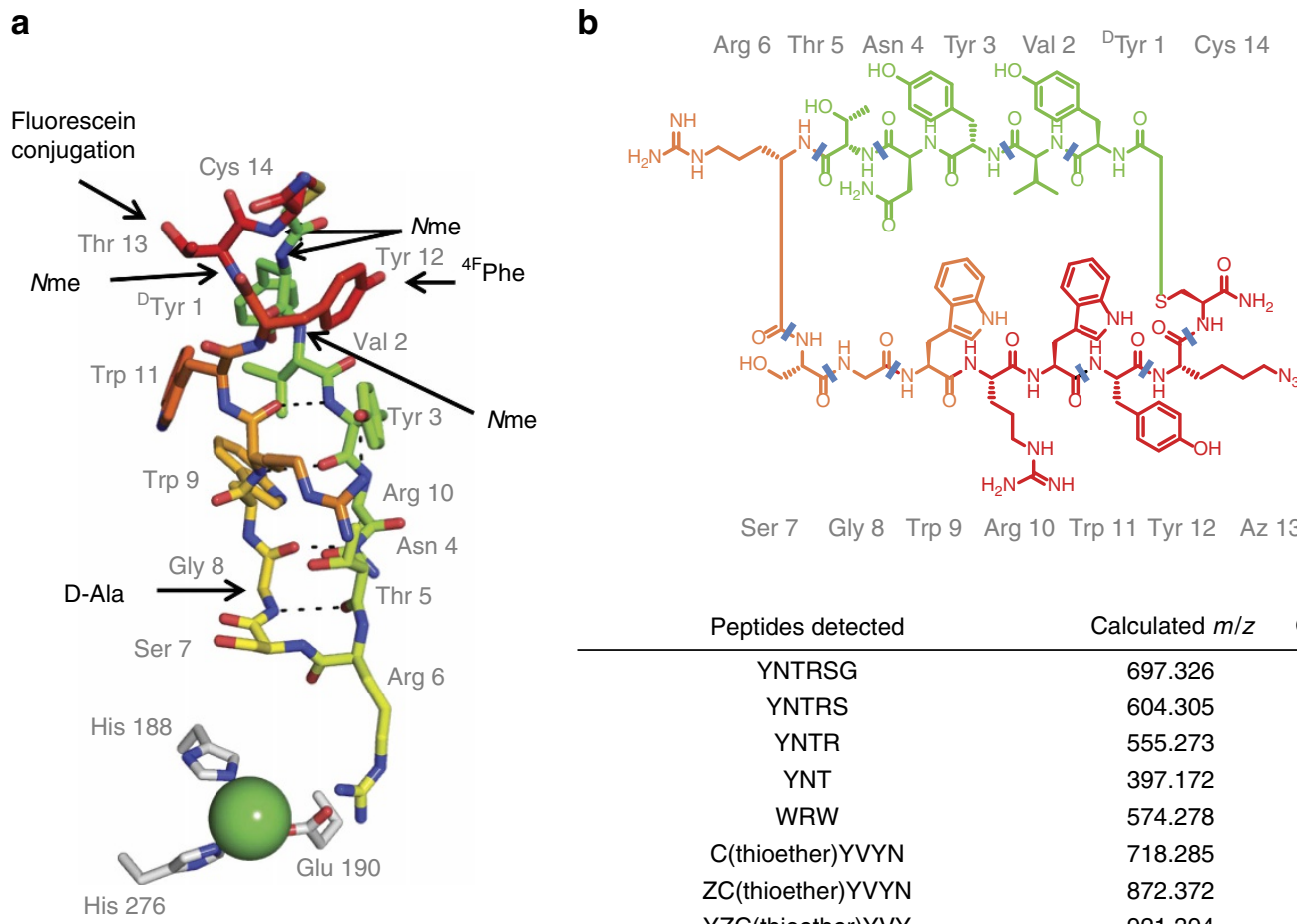

\begin{tabular}{ccc} 
Peptides detected & Calculated $\mathrm{m} / \mathrm{z}$ & Observed $\mathrm{m} / \mathrm{z}$ \\
\hline YNTRSG & 697.326 & 697.326 \\
YNTRS & 604.305 & 604.306 \\
YNTR & 555.273 & 555.273 \\
YNT & 397.172 & 397.174 \\
WRW & 574.278 & 574.278 \\
C(thioether)YVYN & 718.285 & 718.285 \\
ZC(thioether)YVYN & 872.372 & 872.372 \\
YZC(thioether)YVY & 921.394 & 921.394 \\
YZC(thioether)YV or ZC(thioether)YVY & 758.329 & 758.33 \\
\hline
\end{tabular}

Figure 4 | Crystallography and mass spectrometry guided modifications of CP2. (a) Sites of modifications were made based on the crystal structure and MS degradation analysis. (b) MS analysis of degradation fragments of CP2(T13Z) observed on incubation with cell lysate. Cleavage sites are indicated as blue lines.

a

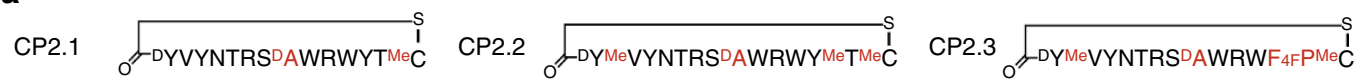

b
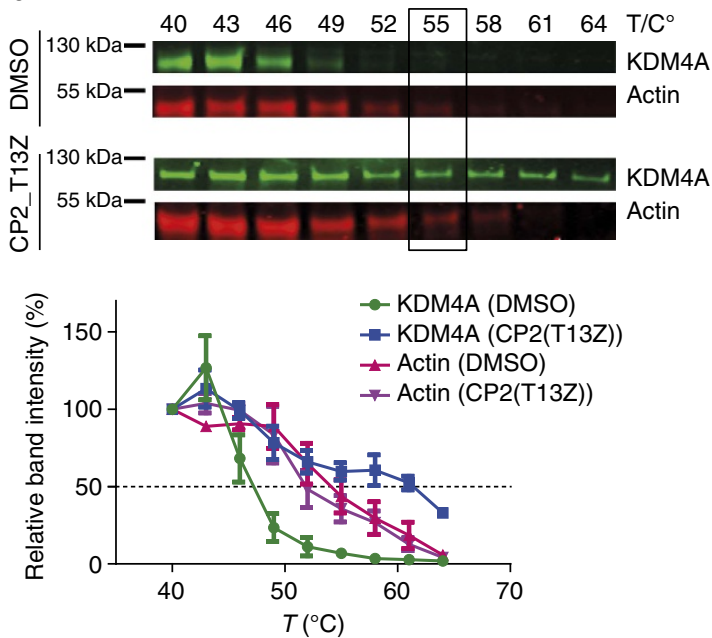

C
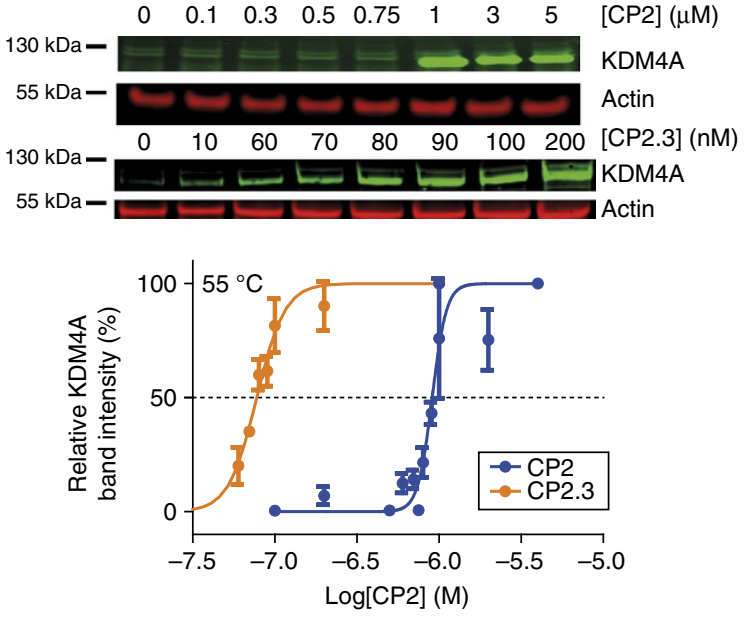

Figure 5 | CP2 derivatives stabilize KDM4A and alter histone methylation status in cells. (a) Sequences of peptides with modifications on CP2 (CP2.1, CP2.2 and CP2.3) used for cellular assays. (b,c) KDM4A stability is enhanced for CP2-treated cells in CETSA. (b) CETSA melting curves for Flag-KDM4A in U2OS cells with and without $\mathrm{CP} 2(\mathrm{~T} 13 \mathrm{Z})$ treatment $(0.5 \mu \mathrm{M})$. The actin $T_{\mathrm{m}}$ was $55^{\circ} \mathrm{C}$ for treated and untreated cells. (c) Isothermal dose-response titration CETSAs of dosed U2OS cells at $55^{\circ} \mathrm{C}$ demonstrate that both CP2 and CP2.3 stabilize KDM4A in a dose-dependent manner. Average \pm s.e.m. are shown ( $n>3$, biological). Representative western blotting figures are shown.

The melting temperature $\left(T_{\mathrm{m}}\right)$ for FLAG-KDM4A was shifted from $47^{\circ} \mathrm{C}$ (dimethyl sulfoxide, DMSO) to $59^{\circ} \mathrm{C}$ with $\mathrm{CP} 2(\mathrm{~T} 13 \mathrm{Z})$ (the precursor to the labeled $\mathrm{CP} 2(\mathrm{Fl})$, peptide 25 ) (Fig. $5 \mathrm{~b}$ and
Supplementary Fig. 6b). Isothermal dose-response function (ITDRF) at $55^{\circ} \mathrm{C}$ revealed FLAG-KDM4A stabilization by $\mathrm{CP} 2$ in a dose-dependent manner $\left(\mathrm{EC}_{50} \sim 1 \mu \mathrm{M}\right)$, supporting 
intracellular target engagement of the inhibitor (Fig. 5c). Correlating with the selective inhibition of $\mathrm{CP} 2$ for isolated KDM4A-C, FLAG-KDM4E was not stabilized under the same CETSA conditions (Supplementary Fig. 8). However, despite apparent intracellular KDM4A engagement, CP2-treated cells did not have any apparent effect on the global histone methylation levels at H3K9me3 and H3K36me3 mark (Supplementary Fig. 12).

Addition of a poly-arginine sequence to $\mathrm{CP} 2$ aimed at enhancing the cellular uptake (CP2(polyR), peptide 11) unexpectedly increased the potency against KDM4s in vitro (KDM4A $\mathrm{IC}_{50}=1.8 \mathrm{nM}, \mathrm{KDM} 4 \mathrm{C} \mathrm{IC}_{50}=0.8 \mathrm{nM}$; Table 2). Interestingly, polyR alone is a potent $\mathrm{KDM} 4 \mathrm{~A}$ inhibitor $\left(\mathrm{IC}_{50}=40 \mathrm{nM}\right)$; thus, the increased potency of $\mathrm{CP} 2$ (polyR) is likely to be a combined effect of the two inhibitory elements. However, although cytotoxicity was observed at high concentrations $(>3 \mu \mathrm{M})$ with significant reduction in cell numbers, no inhibition of cellular KDM4A demethylase activity by CP2(polyR) was detected (Supplementary Figs 11 and 13). An analogous phenomenon has been previously reported with disulphide linked cyclic peptide generated against KDM4C using phage display ${ }^{24}$; the potency of a proposed allosteric binding cyclic peptide inhibitor $\left(\mathrm{IC}_{50}=52 \mu \mathrm{M}\right)$ was improved to $\mathrm{IC}_{50}=0.6 \mu \mathrm{M}$ on addition of a poly arginine/lysine (TAT) tag, but no cell activity was observed. 25

We then modified CP2 by backbone amide $N$-methylation, which is reported to improve peptide stability and cellular uptake. $^{25}$ Guided by the CP2-KDM4A crystal structure (Fig. 2), we synthesized mono $\mathrm{N}$-methylated variants at backbone amide positions not engaging in critical hydrogen bonding interactions with KDM4A and within the CP2 $\beta$-sheet. The selected residues, Cys14, Thr13, Val2 and Tyr1, were mainly in the non-interacting, thioether-linkage region of CP2 (Table 2 and Fig. 4a; peptides 13-16). Mass spectrometric (MS) analysis of CP2 degradation patterns after incubation in cell lysates confirmed that these sites are prone to proteolysis (Fig. $4 \mathrm{~b}$ and Supplementary Fig. 9). D-Ala was also substituted for Gly8 of CP2 with the aim of improving proteolytic stability, as the crystal structure predicted this substitution would be tolerated and hydrolysis at this site was observed by MS (Fig. 4b). 4-Fluorophenylalanine was further incorporated with the aim of improving cellular uptake by increasing hydrophobicity (peptides 17 and 18). Although some of the CP2 modifications reduced activity, in general the structureguided modifications were well tolerated. Combinations of tolerated modifications were prepared (named as CP2.1, CP2.2 and CP2.3, peptides 19-21, respectively) (Table 2, Fig. 5a and Supplementary Fig. 6); Potency and selectivity for KDM4A over other KDM families were maintained for these modified CPs with isolated enzymes. (Supplementary Table 1). Interestingly, the inhibitory effect of CP2.3 against KDM4B was much weaker than for $\mathrm{CP} 2$, but was retained for KDM4A/C. CP2.3 demonstrated greater stability in HeLa cell extracts $\left(t_{1 / 2} \sim 5 \mathrm{~h}\right)$ compared with CP2 $\left(t_{1 / 2} \sim 1 \mathrm{~h}\right)$, as determined by MS (Supplementary Fig. 10). Furthermore, the modified CP2.3 was able to stabilize FLAGKDM4A as observed in CETSA, at concentrations lower than the unmodified CP2 $\left(\mathrm{EC}_{50}<100 \mathrm{nM}\right.$ ) (Fig. 5c), suggesting that the target engagement was maintained on modification and that peptide cellular stability was increased.

We tested CP2.1, CP2.2 and CP2.3 for KDM inhibition in HeLa cells by immunofluorescence analysis of histone methylation marks ( $72 \mathrm{~h}$ treatment). Although application of the CP2 parent gave no discernible changes, treatment with $\mathrm{CP} 2.1-3$ manifested increases in nuclear $\mathrm{H} 3 \mathrm{~K} 9 \mathrm{me} 3 / \mathrm{H} 3 \mathrm{~K} 36 \mathrm{me} 3$ staining over the 10-20 $\mu \mathrm{M}$ inhibitor range (Supplementary Fig. 12a-g). No changes were observed in the apparent $\mathrm{H} 3 \mathrm{~K} 9 \mathrm{me} 3$ levels when cells were treated with the inactive CP2.3(R6A) peptide (peptide
22; Table 2 and Supplementary Fig. 12f). A significant reduction in cell numbers was observed in HeLa cells treated with CP2.1-3 $(>10 \mu \mathrm{M})$ (Supplementary Fig. 12e). As hypermethylation can correlate with cellular stress/toxicity, it is unclear whether the observed hypermethylation is due to on-target KDM4 inhibition or cytotoxic effects, or a combination of these. However, dosing HeLa cells ectopically overexpressing FLAG-KDM4A (wild-type or catalytic inactive mutant H188A) with CP2.3 for $24 \mathrm{~h}$ showed no significant changes in $\mathrm{H} 3 \mathrm{~K} 9 \mathrm{me} 3$ levels (Supplementary Fig. 13) at non-cytotoxic concentration range $(<10 \mu \mathrm{M})$. Thus, the biological relevance of the cellular observations of changes in global histone methylation status following treatment with the KDM inhibitors should be treated with caution.

\section{Discussion}

In conclusion, we have used in vitro selection from a ribosomally synthesized library of cyclic peptides to identify natural productlike inhibitors of KDM4A-C, which act via a previously unidentified binding mode and which have unprecedented selectivity and potency. The RaPID display approach is substantially more efficient than traditional medicinal chemistry and is likely to be of widespread utility in target-based probe discovery. The method is well-suited to identify new inhibitor binding modes, as revealed by the structures of KDM4A complexed with $\mathrm{CP} 2$ and $\mathrm{CP}(\mathrm{R} 6 \mathrm{Kme} 3)$, and associated biochemical results. The binding mode of $\mathrm{CP} 2$ is distinct from reported KDM4C peptide inhibitors (with $\mathrm{IC}_{50}$ values in the $\mu \mathrm{M}$ range) based on the outputs of a phage display library screen, which probably do not bind at the active site (structural studies are not available $)^{24}$. The sequence of CP2 is clearly distinct from that of well-characterized histone substrates for KDM4A-C. The importance of the anchoring residue Arg6 within the CP2 sequence for potent KDM4A inhibition, suggests that arginine residues can compete with methylated lysines binding to KDM4A. This is significant, given the recent findings that some, but not all, JmjC-KDMs, including some KDM4 subfamily members, can also act as $N^{\varepsilon}$-methyl arginine demethylases ${ }^{26}$. KDM4A can both catalyse the demethylation of CP2(R6Kme3) and CP2(R6Rme2a), revealing its potential for modulating both lysine and arginine methylation status in non-histone sequences. Structure- and MS-guided derivatization of an initial hit led to proteolytically more stable macrocycles that stabilize the intracellular target. Changes in the global histone H3K9/K36 methylation status were observed in cells treated with CP2.3 for $72 \mathrm{~h}$, although further studies are needed to link this observation directly to KDM4 inhibition. The biological effects of substrate competing cyclic peptides targeting KDM4A may arise both from simple inhibition of KDM4A catalysis, as well as disruption of its binding to chromatin complex; the latter mechanism is likely to be different to the effect of catalytically inactivating smallmolecule inhibitors, which compete with the 2OG cosubstrate, but not with histone substrates. We also cannot rule out the possibility that the observed intracellular KDM4A stabilization may in part be due to $\mathrm{CP} 2 / \mathrm{CP} 2.3$ proteolytically cleaved fragments, which may, or may not, exert inhibitory effects. Although further studies are necessary to investigate the cell permeability/subcellular distribution, stability and activities of the cyclic peptides, our work highlights the utility of the approach for the generation of potent, substrate competitive and selective KDM inhibitors, and more generally, for developing new approaches to the inhibition of challenging targets.

\section{Methods}

FIT system. Flexizyme RNA and tRNA ${ }^{\text {fMet }}{ }_{\text {CAU }}$ were prepared as reported ${ }^{16}$. $\mathrm{ClAc}^{\mathrm{L}}$ Tyr-tRNA ${ }^{\mathrm{fMet}}{ }_{\mathrm{CAU}}$ and $\mathrm{ClAc}{ }^{\mathrm{D}}$ Tyr-tRNA ${ }^{\mathrm{fMet}}{ }_{\mathrm{CAU}}$ were synthesized by using the reported flexizyme technology ${ }^{11}$. Translation factors, enzymes and ribosome 
were prepared and mixed as previously described ${ }^{27-29}$ to reconstitute an in vitro translation system used for reprogramming of translation initiation ${ }^{11,17}$. The translation reaction mixture contained final concentrations of $50 \mathrm{mM}$ Hepes- $\mathrm{KOH}$ (pH 7.6), $100 \mathrm{mM}$ potassium acetate, $2 \mathrm{mM}$ GTP, $2 \mathrm{mM}$ ATP, $1 \mathrm{mM}$ CTP, $1 \mathrm{mM}$ UTP, $20 \mathrm{mM}$ creatine phosphate, $12 \mathrm{mM} \mathrm{Mg}(\mathrm{OAc})_{2}, 2 \mathrm{mM}$ spermidine, $2 \mathrm{mM}$ dithiothreitol, $1.5 \mathrm{ml}^{-1}$ Escherichia coli total transfer RNA (Roche), $1.2 \mu \mathrm{M}$ ribosome, $0.6 \mu \mathrm{M}$ MTF, $2.7 \mu \mathrm{M}$ IF1, $0.4 \mu \mathrm{M}$ IF2, $1.5 \mu \mathrm{M}$ IF3, $30 \mu \mathrm{M}$ EF-Tu, $30 \mu \mathrm{M}$ EF-Ts, $0.26 \mu \mathrm{M}$ EF-G, $0.25 \mu \mathrm{M}$ RF2, $0.17 \mu \mathrm{M}$ RF3, $0.5 \mu \mathrm{M}$ RRF, $4 \mu \mathrm{g} \mathrm{ml}^{-1}$ creatine kinase, $3 \mu \mathrm{g} \mathrm{ml}^{-1}$ myokinase, $0.1 \mu \mathrm{M}$ pyrophosphatase, $0.1 \mu \mathrm{M}$ nucleotidediphosphatase kinase, $0.1 \mu \mathrm{M}$ T7 RNA polymerase, $0.73 \mu \mathrm{M}$ AlaRS, $0.03 \mu \mathrm{M}$ ArgRS, $0.38 \mu \mathrm{M}$ AsnRS, $0.13 \mu \mathrm{M}$ AspRS, $0.02 \mu \mathrm{M}$ CysRS, $0.06 \mu \mathrm{M}$ GlnRS, $0.23 \mu \mathrm{M}$ GluRS, $0.09 \mu \mathrm{M}$ GlyRS, $0.02 \mu \mathrm{M}$ HisRS, $0.4 \mu \mathrm{M}$ IleRS, $0.04 \mu \mathrm{M}$ LeuRS, $0.11 \mu \mathrm{M}$ LysRS, $0.03 \mu \mathrm{M}$ MetRS, $0.68 \mu \mathrm{M}$ PheRS, $0.16 \mu \mathrm{M}$ ProRS, $0.04 \mu \mathrm{M}$ SerRS, $0.09 \mu \mathrm{M}$ ThrRS, $0.03 \mu \mathrm{M}$ TrpRS, $0.02 \mu \mathrm{M}$ TyrRS, $0.02 \mu \mathrm{M}$ ValRS and $200 \mu \mathrm{M}$ each proteinogenic amino acids, except for methionine, and $50 \mu \mathrm{M} \mathrm{ClAc}{ }^{\mathrm{L}} \mathrm{Tyr}-$ tRNA ${ }_{\text {fMet }}{ }_{\text {CAU }}$ or ClAc ${ }^{\text {Tyr-tRNA }}{ }^{\text {fMet }}{ }_{C A U}$.

Preparation of puromycin-fused mRNA library. RNAs consisting of $4-12$ repeated NNK random sequences (5'-GGGUU, AACUU UAAGA AGGAG AUAUA CAU AUG $(\mathrm{NNK})_{m}$ UGC GGC AGC GGC AGC GGC AGC UAG GACGG GGGGC GGAAA- $3^{\prime}, m=4-12$ ) were prepared by in vitro transcription according to the reported method ${ }^{12}$. The resulting RNAs were mixed in the following ratio- $(\mathrm{NNK})_{4}:(\mathrm{NNK})_{5}:(\mathrm{NNK})_{6}:(\mathrm{NNK})_{7}:(\mathrm{NNK})_{8}:(\mathrm{NNK})_{9}:(\mathrm{NNK})_{10}$ : $(\mathrm{NNK})_{11}:(\mathrm{NNK})_{12}=20^{-3}: 20^{-2}: 20^{-1}: 1: 10: 10: 10: 10: 10$. The mRNA library was ligated with a puromycin linker (5'-CTCCC GCCCC CCGTC C-(SPC18) $)_{5}$-CCpuromycin- $3^{\prime}$ ) by T4 RNA ligase. The ligated product was purified by phenolchloroform extraction and ethanol precipitation.

In vitro selection of cyclic peptides binding to KDM4A. Translation of the first round selection was performed using $156 \mathrm{pmol}$ mRNA-puromycin and $150 \mu \mathrm{l}$ of translation mixture at $37^{\circ} \mathrm{C}$ for $30 \mathrm{~min}$. Subsequently, the translation mixture was incubated at room temperature for $12 \mathrm{~min}$ to conjugate the translated peptide with the corresponding mRNA-puromycin. To this solution was added $15 \mu \mathrm{l}$ of $200 \mathrm{mM}$ EDTA ( $\mathrm{pH} 7.5$ ) then further incubated at $37^{\circ} \mathrm{C}$ for $30 \mathrm{~min}$, to proceed peptide macrocyclization. After exchange with the selection buffer $(50 \mathrm{mM}$ Tris- $\mathrm{HCl}(\mathrm{pH}$ 7.6), $150 \mathrm{mM} \mathrm{NaCl}, 0.05 \%$ Tween 20) by gel filtration, $165 \mu \mathrm{l}$ of blocking solution (100 mM Tris-HCl (pH7.6), $300 \mathrm{mM} \mathrm{NaCl}, 0.2 \%$ acetyl BSA) was added. The resulting peptide library was treated with Dynabeads magnetic beads (His-tag isolation and pulldown, M-280, Invitrogen) at $4{ }^{\circ} \mathrm{C}$ for $30 \mathrm{~min}$. The supernatant was then collected, mixed with KDM4A-immobilized magnetic beads (final concentration of KDM4A was adjusted to $1 \mu \mathrm{M}$ ) and incubated at $4{ }^{\circ} \mathrm{C}$ for $30 \mathrm{~min}$. After the supernatant was removed, the bead was washed three times with $800 \mu \mathrm{l}$ of cold selection buffer. To the bead was added $40 \mu \mathrm{l}$ of room temperature reaction buffer I ( $50 \mathrm{mM}$ Tris- $\mathrm{HCl}$ ( $\mathrm{pH} 8.3$ ), $75 \mathrm{mM} \mathrm{KCl}, 3 \mathrm{mM} \mathrm{MgCl}, 10 \mathrm{mM}$ dithiothreitol, $0.5 \mathrm{mM}$ dNTPs, $2 \mu$ M CGS3an13.R39 (5'-TTTCC GCCCC CCGTC CTAGC TGCCG CTGCC GCTGC CGCA-3')) containing 200 units of M-MLV reverse transcriptase (Promega) and 8 units of RNase inhibitor (Promega), and reverse transcribed at $42^{\circ} \mathrm{C}$ for $60 \mathrm{~min}$. The collected cDNA was eluted with $800 \mu \mathrm{l}$ of PCR buffer ( $10 \mathrm{mM}$ Tris- $\mathrm{HCl}$ (pH 7.5), $50 \mathrm{mM} \mathrm{KCl}, 0.1 \%$ Triton X-100, $2.5 \mathrm{mM}$ $\mathrm{MgCl}_{2}, 0.25 \mathrm{mM}$ dNTPs, $0.25 \mu \mathrm{M}$ T7g10M.F48 (5'-TAATA CGACT CACTA TAGGG TTAAC TTTAA GAAGG AGATA TACAT ATG-3'), $0.25 \mu \mathrm{M}$

CGS3an13.R39) at $95^{\circ} \mathrm{C}$ for $5 \mathrm{~min}$. After addition of Taq DNA polymerase to the eluate, the mixture was used for PCR amplification. The amplified DNA was purified by phenol/chloroform extraction followed by ethanol purification. The resulting DNA library was transcribed in vitro, ligated with the puromycin linker and used for the next round of selection.

For the 2nd-6th rounds of selection, the translation reaction ( $5 \mu \mathrm{l}$ scale) was carried out $\left(37^{\circ} \mathrm{C}\right.$ for $30 \mathrm{~min}$, then room temperature for $\left.12 \mathrm{~min}\right)$. After incubation with $1 \mu \mathrm{l}$ of $100 \mathrm{mM}$ EDTA (pH 7.5) at $37^{\circ} \mathrm{C}$ for $30 \mathrm{~min}, 3.43 \mu \mathrm{l}$ of room temperature reaction buffer II ( $74 \mathrm{mM}$ Tris- $\mathrm{HCl}(\mathrm{pH} 8.3), 44 \mathrm{mM} \mathrm{Mg}(\mathrm{OAc})_{2}$,

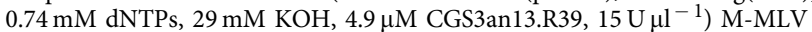
reverse transcriptase without RNase $\mathrm{H}$ activity (Promega)) was added. Reverse transcription of the mRNAs fused on peptides was then performed at $42^{\circ} \mathrm{C}$ for $60 \mathrm{~min}$. After addition of $21 \mu \mathrm{l}$ of selection buffer to the library solution and subsequent buffer exchange with selection buffer by gel filteration, $30 \mu \mathrm{l}$ of blocking solution was added. The resulting peptide library was applied to free Dynabeads magnetic beads at $4{ }^{\circ} \mathrm{C}$ for $30 \mathrm{~min}$ and then the supernatant was recovered (negative selection). After repeating the negative selection step 3 times, half of the recovered peptide solution was mixed with KDM4A-immobilized magnetic beads (final concentration of KDM4A was adjusted to $500 \mathrm{nM}$ ) and incubated at $4{ }^{\circ} \mathrm{C}$ for $30 \mathrm{~min}$. After the supernatant was removed, the beads were washed three times with $60 \mu \mathrm{l}$ of cooled selection buffer. The collected cDNA-mRNA-peptide fusion was recovered with $100 \mu \mathrm{l}$ of PCR buffer by incubation at $95^{\circ} \mathrm{C}$ for $5 \mathrm{~min}$ and amplified by Taq DNA polymerase. The amplified DNA was purified by phenol/ chloroform extraction followed by ethanol purification. The resulting DNA library was transcribed in vitro, ligated with the puromycin linker, then used for the next round of selection. After the fifth and sixth rounds of the selection, the resulting cDNA libraries were cloned into the pGEM-T Easy Vector (Promega) and the individual clones were sequenced.
Peptides. PolyR (Arg)9 peptide was purchased from AnaSpec (AS-621204). The synthesis of peptides used in this study are as described:

Chemical synthesis of selected macrocyclic peptides. Amino acids were from CS Bio, Novabiochem, Sigma, TCI, Alfa Aesar and AGTC Bioproducts. Azidecontaining amino acids were from Iris Biotech, $\mathrm{BCN}$-conjugates for copper-free click chemistry were purchased from Synaffix (Nijmwegen, The Netherlands), Azides for click chemistry were obtained Baseclick (Tutzing, Germany). All peptides were analysed using an Agilent 1200 series LC-MS system (6120 quadrupole MS) with a Waters Sunfire column. Preparative HPLC purifications were carried out using Shimazu prominence LC-20AP system with a Merck Chromolith Prep column $(200-25 \mathrm{~mm})$ or Dionex Ultimate 3,000 system with a Grace Vydac 218TP101522 column.

Method A: peptides were synthesized with an amidated carboxy terminus on a $25 \mu \mathrm{mol}$ scale using NovaPEG Rink Amide resin (Merck) using standard Fmoc protection chemistry. After coupling of the $N$-terminal L-tyrosine or D-tyrosine residue, their Fmoc group was removed. The resulting $\mathrm{N}$-terminal $\alpha$-amino group was chloroacetylated by incubating with a solution of $0.5 \mathrm{M}$ chloroacetyl $\mathrm{N}$ hydroxysuccinimide ester chloromethylcarbonyloxysuccinimide (ClAc-OSu) in $\mathrm{N}$ methylpyrrolidone with rotation for $40 \mathrm{~min}$ at room temperature. After washing the resin with dimethylformamide $(2 \mathrm{ml}$, three times) and dichloromethane $(2 \mathrm{ml}$, six times), the peptides were cleaved from the resin and deprotected by incubation with a solution of trifluoroacetic acid (TFA)/1,2-ethanedithiol/triisopropyl silane/ water $(92.5: 2.5: 2.5: 2.5)$ with rotation at room temperature for $3 \mathrm{~h}$. The solutions were concentrated in vacuo and the cleaved peptides were then precipitated with diethyl ether. The resulting linear peptide pellets were dissolved in $20 \mathrm{ml}$ of water/ DMSO (1:1) and triethylamine was added to the solution to give a $\mathrm{pH}$ of around 10. After incubation at room temperature for $30 \mathrm{~min}$ to effect cyclization, the peptide solution was acidified using TFA then purified by reverse-phase HPLC (Shimazu prominence LC-20AP system with a Merck Chromolith Prep column) in $0.1 \%$ aqueous TFA/acetonitrile containing $0.1 \%$ TFA gradient. The purified peptides were lyophilized and dissolved in DMSO.

Method B: for the synthesis of cyclic peptides, the linear precursors were prepared by standard solid-phase synthesis using a CS Bio CS336X peptide synthesizer $(100 \mu \mathrm{mol}$ scale) using DIC as coupling reagent. For methylated peptides coupling times were tripled for reaction of the amino acid following the $N$-methylated one.

After cleavage of the N-terminal Fmoc-protecting group a solution of $150 \mathrm{mg}$ of $\mathrm{ClAc}$-OSu in $4 \mathrm{ml}$ dimethylformamide was added to the resin and the mixture was shaken for $3 \mathrm{~h}$. The resin was filtered off and subsequently treated with $4 \mathrm{ml}$ of deprotection solution TFA/triisopropyl silane/water (95:2.5:2.5). After $3 \mathrm{~h}$, the volume was reduced to $1 \mathrm{ml}$ under a nitrogen stream and the peptides were precipitated with cold $\mathrm{Et}_{2} \mathrm{O}$. The mixture was centrifuged and the supernatant discarded. The solid was taken up in $1.5 \mathrm{ml}$ of triethylammoniumacetate buffer $(1 \mathrm{M}, \mathrm{pH} 8.5)$ and the $\mathrm{pH}$ readjusted to $>8$ if necessary. In a microwave (Biotage Initiator), the mixture was heated to $80^{\circ} \mathrm{C}$ for $10 \mathrm{~min}$ and subsequently purified by HPLC (0-45\% MeCN in 45 min, 0.1\% TFA, Dionex Ultimate 3,000 series, Grace Vydac 218TP101522 column).

Synthesis of CIAc-OSu. ClAc-OSu was synthesized using a modified literature procedure ${ }^{30}$. A round-bottom flask was charged with $4.00 \mathrm{ml}$ chloroacetylchloride, $6.90 \mathrm{~g}$ of $\mathrm{K}_{2} \mathrm{CO}_{3}$ and $80 \mathrm{ml} \mathrm{CH}_{2} \mathrm{Cl}_{2}$, and cooled to $0^{\circ} \mathrm{C}$. $N$-hydroxysuccinimide $(5.78 \mathrm{~g})$ was dissolved in $80 \mathrm{ml}$ of $\mathrm{MeCN}$ and added slowly to the reaction vessel. The mixture was allowed to warm to room temperature overnight. Subsequently, the slurry was diluted with $500 \mathrm{ml} \mathrm{CH}_{2} \mathrm{Cl}_{2}$, washed with $200 \mathrm{ml} \mathrm{HCl}(1 \mathrm{M})$ and the aqueous layer was then counter-extracted with $500 \mathrm{ml} \mathrm{CH}_{2} \mathrm{Cl}_{2}$. The combined organic layers were dried over $\mathrm{MgSO}_{4}$, then concentrated to give $3.50 \mathrm{~g}(36 \%)$ of chloromethylcarbonyloxysuccinimide as a colourless solid. ${ }^{1} \mathrm{H}$ NMR $(400 \mathrm{MHz}$, $\left.\mathrm{CDCl}_{3}\right): \delta$ (p.p.m.) $=4.37(\mathrm{~s}, 2 \mathrm{H}), 2.85(\mathrm{~s}, 4 \mathrm{H}) .{ }^{13} \mathrm{C} \mathrm{NMR}\left(101 \mathrm{MHz}, \mathrm{CDCl}_{3}\right) \delta$ (p.p.m.) $=168.4,163.2,37.8,25.5$.

Protein expression and purification of KDM4A. N-terminally Hexa-His-tagged KDM4A (His-KDM4A 1-359) $_{\text {) was produced and purified as described }}{ }^{31}$. The KDM4A gene encoding for KDM4A protein (residues 1-359) was cloned into the pNIC-Bio3 plasmid, which incorporates a C-terminal AviTag and expressed with biotin supplement in BL21(DE3)Rosetta co-transfected with pCDF-BirA ${ }^{32}$. HisKDM4A with biotin (His-KDM4A-Bio) was purified using nickel affinity chromatography. Complete ( $>95 \%$ ) biotinylation of KDM4A was confirmed using electrospray ionization-MS (Waters Micromass LCT Premier). The enzyme activity was comparable to that of His-KDM4A and the biotin-tag was demonstrated to be accessible to streptavidin binding as determined by AlphaScreen-binding assay ${ }^{33}$. The full-length FLAG-tagged KDM4A $\mathrm{A}_{1-1,064}$ (ref. 15) was produced in HEK293T cells. HEK293T cells were grown to $80 \%$ confluency in DMEM medium (Sigma) supplemented with Glutamax (Life Technologies), 10\% fetal bovine serum (FBS, Sigma). FLAG-tagged KDM4A was transfected using polyethyleneimine. Cells were harvested after $48 \mathrm{~h}$, washed with PBS (Sigma) and lysed $\left(45 \mathrm{~min}, 4^{\circ} \mathrm{C}\right.$ ) in $50 \mathrm{mM}$ HEPES ( $\left.\mathrm{pH} 7.5\right), 150 \mathrm{mM} \mathrm{NaCl}$ buffer containing protease inhibitor cocktail (Sigma), $10 \mu \mathrm{M}$ DNase (Sigma) and 0.1\% NP40 (Roche). FLAGtagged KDM4A was purified by immunoprecipitation using anti-FLAG M2 magnetic 
beads (Sigma) and washed in in $50 \mathrm{mM}$ HEPES (pH 7.5) $150 \mathrm{mM} \mathrm{NaCl}$. The final wash was performed in $50 \mathrm{mM}$ HEPES $(\mathrm{pH} 7.5)$ and the resin was used as an enzyme source for the full-length KDM4A.

\section{Kinetic measurements. $\mathrm{IC}_{50}$ values for $\mathrm{KDM} 2-6$ were measured using an} AlphaScreen assay as described ${ }^{18}$. The appropriate $\mathrm{KDM}(5 \mu \mathrm{l})$ was pre-incubated with an inhibitor ( $0.1 \mu \mathrm{l}$ in DMSO) or DMSO for $15 \mathrm{~min}$ before the addition of $5 \mu \mathrm{l}$ mixture of biotinylated peptide substrates, 2OG, ferrous ammonium sulfate $(1-10 \mu \mathrm{M}$ final) and ascorbate $(100 \mu \mathrm{M}$ final) to initiate the demethylation reaction. The reaction was quenched with $5 \mu \mathrm{l}$ of $30 \mathrm{mM}$ EDTA at predetermined reaction times for each enzyme (initial rate). Demethylated product was detected by addition of $5 \mu \mathrm{l}$ of AlphaScreen donor and acceptor beads (AlphaScreen General IgG Detection Kit, $0.02 \mathrm{mg} \mathrm{ml}^{-1}$ final each) pre-incubated with antibody. The plates were read after $1 \mathrm{~h}$ incubation in a BMG Labtech Pherastar FS plate reader. Data were normalized to a no enzyme control and $\mathrm{IC}_{50}$ values were calculated using nonlinear regression curve fits using GraphPad Prism. Assay buffer $(50 \mathrm{mM}$ HEPES $\mathrm{pH} 7.5, \mathrm{BSA}(0.1 \% \mathrm{w} / \mathrm{v})$ and Tween-20 $(0.01 \% \mathrm{v} / \mathrm{v}))$ was used throughout, except for dilution of stock ferrous ammonium sulfate solutions where water was used. The enzyme, substrate and antibody concentrations used are described in Supplementary Table 3. A fluorescence-based LSD1 inhibitor screening assay kit (Cayman, 700120) was used for KDM1/LSD1 assay. Assays for prolyl hydroxylase domain 2 and factor inhibiting HIF using matrix-assisted laser desorption/ ionization-time of flight MS were performed as previously described ${ }^{31}$. Prism 5.0 (GraphPad) was used to generate and to fit dose-response curves. $\mathrm{IC}_{50}$ values were determined by plotting percentage inhibition versus compound concentration relative to positive (vehicle) and negative (no enzyme) controls, using normalized dose-response (variable slope) fit. The reported values are the mean of multiple experiments $(n \geq 3)$. The formaldehyde dehydrogenase coupled KDM assay was used to determine the mode of inhibition ${ }^{34}$, using $0.5 \mu \mathrm{M}$ His-KDM4A $\mathrm{A}_{1-359}$. Prism 5.0 (GraphPad) was used to fit in mix-mode inhibition, to determine the kinetic parameters. Binding constants for $\mathrm{CPs}$ and $\mathrm{H} 3(1-15) \mathrm{K} 9 \mathrm{me} 3$ were measured using biolayer interferometry (OctetRed 384, ForteBio) in buffer (50 mM HEPES (pH 7.5), $150 \mathrm{mM} \mathrm{NaCl}, 10 \mu \mathrm{M}$ ammonium iron(II) sulphate). His-KDM4A $\mathrm{A}_{1-359}$-Bio $(70 \mathrm{nM})$ was immobilized onto super streptavidin biosensor and subjected to different peptide concentrations in buffer. Data analysis was performed using ForteBio Data Aalysis (v6.4).

Crystallography. The KDM4A.CP2 complex was prepared by adding CP2 to a final concentration of $0.2 \mathrm{mM}$ in a solution of $0.25 \mathrm{mM}\left(11 \mathrm{mg} \mathrm{ml}^{-1}\right)$ His$\mathrm{KDM}_{4-35}$ in gel filtration buffer (10 mM HEPES pH 7.5, $500 \mathrm{mM} \mathrm{NaCl}$ and $5 \%$ glycerol). Crystals were grown by vapour diffusion at $4{ }^{\circ} \mathrm{C}$ in $200 \mathrm{nl}$ sitting drops with a $1: 1$ ratio of sample to well solution $(0.1 \mathrm{M}$ propionate-cacodylate-bis-tris propane $\mathrm{pH} 9.0$ and $25 \% \mathrm{w} / \mathrm{v}$ polyethylene glycol 1,500). Crystals of KDM4A.CP2(R6Kme3) complex (0.25 mM His-KDM4A $\mathrm{A}_{1-359}, 1 \mathrm{mM} \mathrm{NiCl}_{2}$, $2.5 \mathrm{mM}$ NOG and $5 \mathrm{mM} \mathrm{CP} 2$ (R6Kme3) were grown by vapour diffusion at $4{ }^{\circ} \mathrm{C}$ in $300 \mathrm{nl}$ sitting drops with a 1:2 ratio of sample to well solution ( $0.1 \mathrm{M}$ bicine $\mathrm{pH} 9.0$ and $10 \% \mathrm{w} / \mathrm{v}$ polyethylene glycol 6,000$)$. Crystals were cryo-protected by transferring to a solution of mother liquor supplemented with $25 \% \mathrm{v} / \mathrm{v}$ glycerol before being flash frozen in liquid $\mathrm{N}_{2}$. An additional $0.5 \mathrm{mM} \mathrm{CP2}$ was added to the cryoprotectant for KDM4A.CP2 crystals.

Data were collected from single crystals at $100 \mathrm{~K}$ at the Diamond Light Source, beamline I04-1. Data for the KDM4A.CP2 complex were processed using XDS ${ }^{35}$ and SCALA ${ }^{36}$; data for the CP2(R6Kme3) complex were processed using HKL2000 (ref. 37). The structures were solved by molecular replacement using PHASER ${ }^{38}$ and PDB 2OX0 as the initial model. The majority of the KDM4A.CP2 structure refinement was carried out with Phenix ${ }^{39}$, with iterative rebuilding of the model using $\mathrm{COOT}^{40}$. Final rounds of slowcool-simulated annealing refinement using the maximum-likelihood function and bulk-solvent modelling in $\mathrm{CNS}^{41}$ proceeded until the decreasing $R / R_{\text {free }}$ no longer converged. KDM4A.CP2(R6Kme3) complex was refined by alternative cycles of $\mathrm{CNS}^{41}$ and PHENIX ${ }^{39}$ using the ML function and bulk-solvent modelling. All residues were in acceptable regions of the Ramachandran plot as calculated by PROCHECK ${ }^{42}$ and/or MOLPROBITY ${ }^{43}$. Data collection and refinement statistics are in Supplementary Table 2.

Cell culture. HEK293T, HeLa and U2OS cells were obtained from the ATCC (LGC Standards, UK). FBS, L-glutamine and DMEM medium were purchased from Sigma; PBS and OptiMEM were from ThermoFisher Scientific. All cell lines were cultured in DMEM supplemented with $10 \% \mathrm{FBS}, 2 \mathrm{mM}$ L-glutamine and $1 \times$ PenStrep at $37^{\circ} \mathrm{C}$ and $5 \% \mathrm{CO}_{2}$ unless otherwise stated.

MS-based peptide degradation assay. HEK 293T cells (approximately $1 \times 10^{7}$ cells) in a $75 \mathrm{~cm}^{2}$ flask were washed with PBS, harvested with trypsin, quenched with $10 \%$ FBS (Sigma)-containing DMEM (Sigma) and centrifuged at $200 \mathrm{~g}$ for $3 \mathrm{~min}$ at $4{ }^{\circ} \mathrm{C}$. The pelleted cells were re-suspended in $1 \mathrm{ml}$ buffer containing $20 \mathrm{mM}$ Tris- $\mathrm{HCl}(\mathrm{pH} \mathrm{7.6)}$ and $140 \mathrm{mM} \mathrm{NaCl}$. The suspension was freeze-thawed five times using liquid nitrogen and a heating block set at $25^{\circ} \mathrm{C}$, vortexing briefly between each thawing, followed by centrifugation $\left(14,000 \mathrm{~g}, 10 \mathrm{~min}, 4^{\circ} \mathrm{C}\right)$.

$\mathrm{CP} 2$ (T13Z) was added to $250 \mu \mathrm{l}$ lysate, yielding a final concentration of $200 \mu \mathrm{M}$ peptide. The contents were incubated at $37{ }^{\circ} \mathrm{C}$ and $30 \mu \mathrm{l}$ aliquots withdrawn at various time points. Analyses were performed using a Thermo Exactive mass spectrometer equipped with Waters Acquity liquid chromatography system. Instrument control and data processing were performed using Thermo Xcalibur Software. The system was calibrated on the day of the analysis. The mass accuracy with external calibration (as used for these experiments) was better than $5 \mathrm{ppm}$ for 24 hours following calibration. Electrospray source conditions were adjusted to maximize sensitivity. Each sample $(1 \mu \mathrm{l})$ was injected into the system with a $2.1 \times 50 \mathrm{~mm}(3 \mu \mathrm{m})$ Purospher STAR RP-18 endcapped column at a flow rate of $0.4 \mathrm{ml} \mathrm{min}^{-1}$. The oven was held at $40^{\circ} \mathrm{C}$ throughout the analysis. Solvent $\mathrm{A}$ was aqueous $0.1 \%$ formic acid and solvent $B$ was acetonitrile. Peptides were eluted from the column using a gradient of $5-100 \%$ solvent B over 8 min. All raw data files were analysed with MestReNova V.10.

Cell thermal stability assays. For CETSA melting curve experiments, $80 \%$ confluent U2OS cells in a $75 \mathrm{~cm}^{2}$ flask were transfected with a plasmid encoding full-length Flag-tagged $\mathrm{KDM}_{4} \mathrm{~A}_{1-1,064}$ (ref. 15) or $\mathrm{KDM}_{4} \mathrm{E}_{1-506}$ (ref. 20) using Lipofectamine 2000 (Thermo Scientific) and incubated for $4 \mathrm{~h}$. The cells were washed with PBS buffer and media replaced with fresh DMEM with $10 \%$ FBS, supplemented with cyclic peptides in DMSO (0.1\% DMSO final). Cell dosing was carried out for $20 \mathrm{~h}$ at $37^{\circ} \mathrm{C}$. Control cells were dosed only with DMSO. The cells were trypsinized and washed thrice with PBS, by centrifugation $\left(300 \mathrm{~g}, 3 \mathrm{~min}, 4^{\circ} \mathrm{C}\right)$. Cells were re-suspended in PBS supplemented with Complete Protease inhibitor cocktail (Sigma) and divided into $8-10$ aliquots $(100 \mu \mathrm{l})$ containing equal cell numbers in PCR tubes. For ITDRF CETSA experiments, approximately $6 \times 10^{6}$ cells were seeded evenly into nine $25 \mathrm{~cm}^{2}$ flask and adhered before transfection. After $4 \mathrm{~h}$ of incubation, the cells were washed with PBS buffer and the media replaced with fresh DMEM with 10\% FBS supplemented with cyclic peptides at a final concentration between 0 and $4,000 \mathrm{nM}(0.1 \%$ DMSO final). Cells were trypsinized and washed thrice with PBS using centrifugation $\left(300 \mathrm{~g}, 3 \mathrm{~min}, 4^{\circ} \mathrm{C}\right)$. Cells were re-suspended in PBS supplemented with protease inhibitor cocktail (Sigma), aliquots $(100 \mu \mathrm{l})$ containing equal cell numbers in PCR tubes were prepared. For CETSA melting curve experiments, each PCR tube was incubated for $3 \mathrm{~min}$ in a heating block at different temperatures, then at room temperature for $3 \mathrm{~min}$. For ITDRF, tubes were incubated at approximately the $T_{\mathrm{m}}$ of the proteins of interest as determined by CETSA melting curve experiments, for example, $55^{\circ} \mathrm{C}$ ( $T_{\mathrm{m}}$ for actin) for $3 \mathrm{~min}$, followed by room temperature for $3 \mathrm{~min}$. The tubes were centrifuged $\left(300 \mathrm{~g}, 3 \mathrm{~min}, 4^{\circ} \mathrm{C}\right)$. The supernatant was removed and cells suspended in lysis buffer (100 mM HEPES, $300 \mathrm{mM} \mathrm{NaCl}, 2 \% \mathrm{NP}-40$ and $10 \mathrm{mM} \mathrm{EDTA}, \mathrm{pH} 7.4)$, supplemented with protease inhibitor cocktail. The tubes were incubated at $4{ }^{\circ} \mathrm{C}$ for $1 \mathrm{~h}$, with vortexing every $20 \mathrm{~min}$. Samples were centrifuged for $30 \mathrm{~min}$ at $>16,000 \mathrm{~g}$ at $4{ }^{\circ} \mathrm{C}$ to pellet cell debris and precipitated proteins.

The samples (supernatant) were run on SDS-PAGE (NuPage Novex Bis-Tris 4-12\% polyacrylamide gels with NuPAGE MES SDS running buffer (Thermo Scientific)) and transferred onto nitrocellulose membranes using either the iBlot blotting system. FLAG-KDM4A levels were determined by immunoblotting using a monoclonal mouse anti-FLAG primary antibody (F1804, Sigma), at a dilution of 1: 1,000 in PBS-T buffer containing Seablock Reagent Salmon Plasma ( $2 \% \mathrm{v} / \mathrm{v}$, Calbiochem). An additional chicken anti- $\beta$-actin primary antibody (ab13822, Abcam) was also used. A goat anti-mouse fluorescent secondary antibody $(800 \mathrm{~nm}$, 1:10,000, Thermo Scientific) and anti-chicken fluorescent secondary antibody ( $680 \mathrm{~nm}, 1: 10,000$, Thermo Scientific) were used for imaging on a LI-COR Odyssey CLx imaging system. Western blotting band intensities were quantified using Image Studio Ver. 3.1 (LI-COR Biosciences) and plotted in Prism 6.07 software (GraphPad Software Inc.) to generate thermal stability curves.

Data availability. The crystal structures KDM4A.Ni(II).CP2 and KDN4A.$\mathrm{Ni}(\mathrm{II})$.CP2(R6Kme3) have been deposited under PDB accession codes 5LY1 and 5LY2, respectively. All other data are available from the authors upon reasonable request.

\section{References}

1. Bannister, A. J. \& Kouzarides, T. Regulation of chromatin by histone modifications. Cell Res. 21, 381-395 (2011).

2. Bonasio, R., Tu, S. \& Reinberg, D. Molecular signals of epigenetic states. Science 330, 612-616 (2010).

3. Dawson, M. A. \& Kouzarides, T. Cancer epigenetics: from mechanism to therapy. Cell 150, 12-27 (2012).

4. Pedersen, M. T. \& Helin, K. Histone demethylases in development and disease. Trends Cell Biol. 20, 662-671 (2010).

5. Mosammaparast, N. \& Shi, Y. Reversal of histone methylation: biochemical and molecular mechanisms of histone demethylases. Annu. Rev. Biochem. 79, 155-179 (2010).

6. Shi, Y. et al. Histone demethylation mediated by the nuclear amine oxidase homolog LSD1. Cell 119, 941-953 (2004).

7. Klose, R. J., Kallin, E. M. \& Zhang, Y. JmjC-domain-containing proteins and histone demethylation. Nat. Rev. Genet. 7, 715-727 (2006).

8. Hojfeldt, J. W., Agger, K. \& Helin, K. Histone lysine demethylases as targets for anticancer therapy. Nat. Rev. Drug Discov. 12, 917-930 (2013). 
9. McAllister, T. E. et al. Recent progress in histone demethylase inhibitors. J. Med. Chem. 59, 1308-1329 (2016).

10. Hipolito, C. J. \& Suga, H. Ribosomal production and in vitro selection of natural product-like peptidomimetics: the FIT and RaPID systems. Curr. Opin. Chem. Biol. 16, 196-203 (2012).

11. Yamagishi, Y. et al. Natural product-like macrocyclic N-methyl-peptide inhibitors against a ubiquitin ligase uncovered from a ribosome-expressed de novo library. Chem. Biol. 18, 1562-1570 (2011).

12. Hayashi, Y., Morimoto, J. \& Suga, H. In vitro selection of anti-Akt2 thioethermacrocyclic peptides leading to isoform-selective inhibitors. ACS Chem. Biol. 7, 607-613 (2012).

13. Tanaka, Y. et al. Structural basis for the drug extrusion mechanism by a MATE multidrug transporter. Nature 496, 247-251 (2013).

14. Whetstine, J. R. et al. Reversal of histone lysine trimethylation by the JMJD2 family of histone demethylases. Cell 125, 467-481 (2006).

15. Klose, R. J. et al. The transcriptional repressor JHDM3A demethylates trimethyl histone H3 lysine 9 and lysine 36. Nature 442, 312-316 (2006).

16. Goto, Y., Katoh, T. \& Suga, H. Flexizymes for genetic code reprogramming. Nat. Protoc. 6, 779-790 (2011).

17. Goto, Y. et al. Reprogramming the translation initiation for the synthesis of physiologically stable cyclic peptides. ACS Chem. Biol. 3, 120-129 (2008).

18. Rose, N. R. et al. Plant growth regulator daminozide is a selective inhibitor of human KDM2/7 histone demethylases. J. Med. Chem. 55, 6639-6643 (2012).

19. Chen, Z. et al. Structural basis of the recognition of a methylated histone tail by JMJD2A. Proc. Natl Acad. Sci. USA 104, 10818-10823 (2007).

20. Hillringhaus, L. et al. Structural and evolutionary basis for the dual substrate selectivity of human KDM4 histone demethylase family. J. Biol. Chem. 286, 41616-41625 (2011)

21. Debets, M. F. et al. Bioconjugation with strained alkenes and alkynes. Acc. Chem. Res. 44, 805-815 (2011).

22. Dommerholt, J. et al. Readily accessible bicyclononynes for bioorthogonal labeling and three-dimensional imaging of living cells. Angew. Chem. Int. Ed. 49, 9422-9425 (2010).

23. Jafari, R. et al. The cellular thermal shift assay for evaluating drug target interactions in cells. Nat. Protoc. 9, 2100-2122 (2014).

24. Leurs, U. et al. Substrate- and cofactor-independent inhibition of histone demethylase KDM4C. ACS Chem. Biol. 9, 2131-2138 (2014).

25. White, T. R. et al. On-resin N-methylation of cyclic peptides for discovery of orally bioavailable scaffolds. Nat. Chem. Biol. 7, 810-817 (2011).

26. Walport, L. J. et al. Arginine demethylation is catalyzed by a subset of JmjC histone lysine demethylases. Nat. Commun. 7, 11974 (2016).

27. Clemons, Jr W. M. et al. Crystal structure of the 30 S ribosomal subunit from Thermus thermophilus: purification, crystallization and structure determination. J. Mol. Biol. 310, 827-843 (2001).

28. Shimizu, Y. et al. Cell-free translation reconstituted with purified components. Nat. Biotechnol. 19, 751-755 (2001).

29. Josephson, K., Hartman, M. C. \& Szostak, J. W. Ribosomal synthesis of unnatural peptides. J. Am. Chem. Soc. 127, 11727-11735 (2005).

30. Woods, M. \& Sherry, A. D. An improved and versatile synthetic route to 6,7:13,14-dibenzo-1,8,4,11-dioxadiazacyclotetradecane. Inorg. Chim. Acta 351, 395-398 (2003)

31. King, O. N. et al. Quantitative high-throughput screening identifies 8-hydroxyquinolines as cell-active histone demethylase inhibitors. PLOS ONE 5, e15535 (2010).

32. Keates, T. et al. Expressing the human proteome for affinity proteomics: optimising expression of soluble protein domains and in vivo biotinylation. New Biotechnol. 29, 515-525 (2012).

33. Kawamura, A. et al. Development of homogeneous luminescence assays for histone demethylase catalysis and binding. Anal. Biochem. 404, 86-93 (2010).

34. Chowdhury, R. et al. The oncometabolite 2-hydroxyglutarate inhibits histone lysine demethylases. EMBO Rep. 12, 463-469 (2011).

35. Kabsch, W. Integration, scaling, space-group assignment and post-refinement. Acta Crystallogr. D Biol. Crystallogr. 66, 133-144 (2010).

36. Winn, M. D. et al. Overview of the CCP4 suite and current developments. Acta Crystallogr. D Biol. Crystallogr. 67, 235-242 (2011).

37. Otwinowski, Z. \& Minor, W. Processing of X-ray diffraction data collected in oscillation mode. Method Enzymol. 276, 307-326 (1997).

38. McCoy, A. J. et al. Phaser crystallographic software. J. Appl. Crystallogr. 40, 658-674 (2007).
39. Adams, P. D. et al. PHENIX: a comprehensive Python-based system for macromolecular structure solution. Acta Crystallogr. D Biol. Crystallogr. 66, 213-221 (2010).

40. Emsley, P. \& Cowtan, K. Coot: model-building tools for molecular graphics. Acta Crystallogr. D Biol. Crystallogr. 60, 2126-2132 (2004).

41. Brunger, A. T. et al. Crystallography \& NMR system: a new software suite for macromolecular structure determination. Acta Crystallogr. D Biol. Crystallogr. 54, 905-921 (1998).

42. Laskowski, R. A., Macarthur, M. W., Moss, D. S. \& Thornton, J. M. Procheck-a Program to check the stereochemical quality of protein structures. J. Appl. Crystallogr. 26, 283-291 (1993).

43. Chen, V. B. et al. MolProbity: all-atom structure validation for macromolecular crystallography. Acta Crystallogr. D Biol. Crystallogr. 66, 12-21 (2010).

\section{Acknowledgements}

We thank Dr Jumpei Morimoto for invaluable discussions and James Wickens for his assistance in MS analysis. This work was supported by the JSPS Grant-in-Aid for the Specially Promoted Research (21000005), the Core Research for Evolutional Science and Technology (CREST) Program of Japan Science and Technology Agency (JST), BHF Centre of Research Excellence Oxford (RE/08/004), Engineering and Physical Sciences Research Council (EP/L003376/1), Cancer Research UK (C8717/A18245), the People Programme (Marie Curie Actions) of the European Union's Seventh Framework Programme (FP7/2007-2013) under REA grant agreement number 298603 (Marie Curie IEF Fellowship to M.M.), the Wellcome Trust, and the European Research Council Starter Grant (679479). R.J.H. acknowledges a William R Miller Junior Research Fellowship from St Edmund Hall Oxford and A.K. is supported by the Royal Society Dorothy Hodgkin Research Fellowship. The SGC is a registered charity (number 1097737) that receives funds from AbbVie, Boehringer Ingelheim, the Canada Foundation for Innovation, the Canadian Institutes for Health Research, Genome Canada, GlaxoSmithKline, Janssen, Lilly Canada, the Novartis Research Foundation, the Ontario Ministry of Economic Development and Innovation, Pfizer, Takeda and the Wellcome Trust (092809/Z/ $10 / Z)$

\section{Author contributions}

H.S., C.J.S. and A.K. conceived and designed the study experiments, and drafted the manuscript. T.K. and T. Kato performed the RaPID selections. T.K., Y.G., M.M. and R.J.H. synthesized the peptides. A.K., A.T., O.N.F.K. and B.B. conducted in vitro analysis and MS, and protein crystallography was carried out by R.C., O.N.F.K. and S.M. The cellbased assay was performed by A.K., C.Y., B.B., S.B.H., L.J.W. and T.P. All authors analysed the experimental data, discussed the results and were involved in preparation of the manuscript.

\section{Additional information}

Supplementary Information accompanies this paper at http://www.nature.com/ naturecommunications

Competing interests: The authors declare no competing financial interests.

Reprints and permission information is available online at http://npg.nature.com/ reprintsandpermissions/

How to cite this article: Kawamura, A. et al. Highly selective inhibition of histone demethylases by de novo macrocyclic peptides. Nat. Commun. 8, 14773 doi: 10.1038/ ncomms14773 (2017)

Publisher's note: Springer Nature remains neutral with regard to jurisdictional claims in published maps and institutional affiliations.

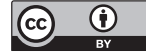

This work is licensed under a Creative Commons Attribution 4.0 International License. The images or other third party material in this article are included in the article's Creative Commons license, unless indicated otherwise in the credit line; if the material is not included under the Creative Commons license, users will need to obtain permission from the license holder to reproduce the material. To view a copy of this license, visit http://creativecommons.org/licenses/by/4.0/

(C) The Author(s) 2017 